\title{
Examining the everyday micro-economies of migrant detention in the United States
}

\author{
D. Conlon ${ }^{1, *}$ and N. Hiemstra ${ }^{2, *}$ \\ ${ }^{1}$ University of Leeds, Leeds, UK \\ ${ }^{2}$ Stony Brook University, New York, USA \\ *These authors contributed equally to this work.
}

Correspondence to: D. Conlon (d.conlon@leeds.ac.uk)

\begin{abstract}
Received: 5 April 2014 - Revised: 16 December 2014 - Accepted: 16 December 2014 - Published: 22 December 2014
\end{abstract}
\begin{abstract}
Securitization of immigration, the rise of interior immigration policing, and forces of carceral privatization have occasioned a remarkable expansion of immigrant detention throughout the United States. Previous studies have drawn attention to the importance of the daily rates paid by the federal government to individual facilities in driving the emphasis on detention. This paper, in contrast, argues that tracing the political and economic geography of money inside detention facilities is also critical for understanding detention expansion and its consequences. We define the processes, mechanisms, and practices of generating profit above and beyond the "per-bed" daily rate as "internal micro-economies" of migrant detention. Drawing on an ongoing examination of migrant detention facilities in the greater New York City metropolitan area, we identify four micro-economies evident in detention facilities: the commissary systems, phone and other forms of communication, detainee labor, and detainee excursions outside detention. These economies show how detained migrants' needs and daily routines are tailored in ways that produce migrants as both captive consumers and laborers. Recognition of multiple micro-economies also highlights the fact that the numbers of individuals and entities invested in the incarceration of immigrants proliferate in tandem with the objectification of detainees. The paper further suggests that attending to relationships embedded in the inner workings of detention exposes economic links across carceral boundaries, rendering visible the porosity between government, private companies, and publics.
\end{abstract}

\section{Introduction}

Seemingly ever increasing numbers of immigrants in the United States - and elsewhere - are incarcerated while awaiting immigration and deportation hearings, in facilities including county- and state-operated prisons and privately managed detention centers. From 2005 to 2010, the number of migrants detained in the US increased from 280000 to approximately 400000 individuals annually. Immigration and Customs Enforcement (ICE) now detains an average of 33000 migrants on a daily basis (Office of Immigration Statistics, 2012). Indeed, Congress has put into place a 34000 -detainee-per-day bed mandate, essentially requiring ICE to aim for that number of detainees per day (Miroff, 2013).

Amidst ongoing, and famously contentious, efforts to reform the US immigration system, detention continues to be a largely unchallenged keystone of enforcement policy, despite evidence that there are much cheaper, equally effective, and less disruptive means for keeping track of immigrants prior to court appearances and deportation (Detention Watch Network, 2014a). Justifications for immigrant detention over other options are typically couched in an overt logic of national security whereby rationales of containing dangerous bodies, controlling membership in the nation, and protecting borders essentially become instruments used to protect and extend the power of the US state (Bigo, 2002; Fernandes, 2007; Barry, 2009a). While these public discourses of security are undeniably important influences, a growing body of scholarly and activist research calls for consideration of equal or perhaps more powerful hidden logics behind the growing detention estate: economic gain. There has been attention to privatization of the "migration industry" 
as a key driver of the expanding detention apparatus (Fernandes, 2007; Golash-Boza, 2009). Private companies now operate almost half (49\%) of all immigrant detention beds; in contrast, private companies operate approximately $8 \%$ of state and federal prison beds (Detention Watch Network, nd). Also, in this era of reduced federal support for local and regional governments, immigrant detention has become a revenue-generating strategy for many counties that open up their existing prison system or work in partnership with private corporations to build new facilities specifically for immigrant detention (Fernandes, 2007; Barry, 2009a).

With the increasing targeting of detention as a profit generator, there are increased demands for economies of scale in the interest of maintaining cost-effective operations that beget profit. Attention to the economics of detention tends to be directed to the daily rates received by detention facilities from the federal government: an average of USD 164 per day, totaling over USD 1.7 billion per year (Detention Watch Network, 2014a). We describe these rates as part of a macrolevel calculus, which plays a significant role in the continued ideological drive for and financial investment in detention. In this paper, however, we focus on additional ways in which money is made from immigration detention. Within most detention facilities - whether run by federal, state, or county governments or private companies - many elements are further contracted out to private entities. Drawing on an ongoing examination of migrant detention facilities in the greater New York City metropolitan area, this paper calls attention to ways in which components of the infrastructure of detention are used to exploit detainees and generate profit from migrant detention. We define the processes, mechanisms, and practices of generating profit above and beyond the "per-bed" daily rate as "internal micro-economies" of migrant detention. We identify four micro-economies, describe how they are constructed and maintained within the spaces of detention, and argue that immigrant detention in the United States is structured to effectively turn detainees into captive and coerced consumers and laborers in ways that generate revenue for a wide range of actors. Further, we illustrate that attending to such hard-to-access spaces exposes economic links across carceral boundaries, rendering visible the porosity between government, private companies, publics, and the everyday micro-economies of migrant detention.

The paper first reviews previous work on the growth of immigrant detention vis-à-vis shifts in immigration enforcement and border control policies. Paying particular attention to the relationship between the expansion of immigrant detention and private industry, we make the case for a focus on the micro-economies of detention. Then, drawing on our current research, we identify and explore four specific microeconomies through which profits are extracted from detained migrants: the commissary systems, phone and other forms of communication, detainee labor, and detainee excursions outside detention. The paper concludes by suggesting that identification and analysis of everyday micro-economies of detention facilities are essential to understanding - and undermining - the expanding detention regime.

\section{Detention privatization: an overview of macro- and micro-level expansion of the immigration industrial complex}

While popular discourses link the expansion of immigrant detention to border control and national security in the postSeptember 11th era, the massive increase in numbers of immigrants detained and in the privatization of detention space actually began in the 1980s. In 1984 the precursor to Immigration and Customs Enforcement (ICE), a division of the Department of Homeland Security (DHS) responsible for enforcement, entered into contracts with Corrections Corporation of America (CCA) and Wackenhut Services Inc. - now GEO Group - to open the first privatized immigration detention facilities in the US (Dow, 2004:97; Barry, 2009b). Privatization again surged in the 1990s, fueled by passage of harsh immigration laws in 1996 that expanded grounds for the detention and deportation of undocumented immigrants.

In the wake of the attacks of 2001, in 2003, and again in 2006, policies further criminalizing immigrants were put in place which significantly expanded the potential detention population and, consequently, opportunities for profiting from detention (Cervantes-Gautschi, 2010). These included expansion of a class of offenses reserved for immigrants referred to as "aggravated felonies", and the replacement of "catch-and-release" programs with a "catch-and-return" policy (Martin, 2012). Mandatory detention while immigrants await immigration status hearings is at the heart of both of these changes. Another key shift entails the decentralization and dispersement of immigration enforcement functions to local communities, through programs such as $287(\mathrm{~g})$, introduced in 1996, and Secure Communities, introduced in 2008. This shift in the geography of border enforcement - from the border to interior spaces - produces an ever-widening swath of sites, whence immigrants can come into contact with the detention system (Coleman, 2007, 2009; Varsanyi, 2008). It has also resulted in greatly increased demand for detention bed space. The "geometric expansion of immigration detention" (Doty and Wheatley, 2013:427; Feltz and Baksh, 2012) means record breaking numbers of individuals are detained; for example, the 2012 figure of 478000 immigrants detained by ICE represented "an all-time high" (Simanski and Sapp, 2013:1) detainee population. With this, private corporations such as CCA and GEO Group established themselves as leading providers in the "immigration industrial complex" (Fernandes, 2007; Golash-Boza, 2009).

Other factors, too, have been instrumental in bolstering the role of private corporations in immigration detention. For instance, in the 1980 s the move to divest government funds from detention - and prison space more broadly was welcomed in an era marked by tight fiscal budgets and 
the burgeoning embrace of neoliberalism, the prevailing "institutional framework characterized by strong private property rights, free markets, and free trade" (Harvey, 2005:2). In immigration detention, privatization was believed to foster greater flexibility to deal with a fluctuating detainee population (Barry, 2009a). Thus, today, privatization is a cornerstone in the business models of corporations including CCA, GEO Group, and Management and Training Corporation (MTC). Indeed, in 2006, the CCA president and CEO, John Ferguson, told investors "we've never seen the wind at our back like it is today" (cited in Feltz, 2008:30).

Academic scholarship and policy reports tend to focus on macro-level issues in private immigration detention. Research highlights the enormous increases in revenues for private corporations generated by privatized detention. For example, in 2010, CCA's annual revenue was USD 1.69 billion, an increase of $88 \%$ over 2001 income levels. In the same year, GEO Group reported annual revenues of USD 1.17 billion, a $121 \%$ increase over 2002 figures (Justice Policy Institute, 2011; Detention Watch Network, 2014a). The relationship between privatized profits and the daily cost of detention borne by taxpayers via the federal government has garnered critical attention. Feltz and Baksh (2012), for example, highlight the relationship between campaign contributions by corporations such as CCA and lawmakers' positions on funding detention and related punitive immigration policies. Such lobbying efforts alongside the revolving door of personnel and advisors between federal immigration enforcement agencies and private sector detention operators illuminate the blurred boundaries between public and private sectors in immigration enforcement. As more components of the "immigration industrial complex" have been turned over to private actors, there is increasing "lack of clarity about who is primarily responsible for the humane care of imprisoned immigrants" (Barry, cited in Kerwin and Lin, 2009:9). With this, advocates and researchers are compelled to question and draw attention to conditions within detention facilities. National and regional reports detail many of the problems that detainees encounter routinely whilst detained (see, for example, Amnesty International, 2009; N.Y.U. Immigrant Rights Clinic, 2010; ACLU, 2011). Issues identified include the high cost and poor quality of access to communications, the quality and quantity of food service, and the availability of adequate medical care. In addition to detailing the inadequacies that pervade service provision in immigration detention, studies highlight the challenges involved in holding private companies and contracted service providers accountable to standards laid out in the Performance-Based National Detention Standards (PBNDS), which were first implemented in 2000, revised by the Obama administration in 2008, and again in 2011. Among the reports that precipitated revision of the 2008 standards is an oft-cited review of conditions in 25 detention facilities, authored by Dora Schriro under the auspices of ICE's Office of Detention Policy and Planning (Schriro, 2009). The report identified the absence of systematic information on agreements and renewals between ICE and contracted service providers in detention centers as well as a lack of consolidated records on "vendor performance". This remains an issue today and is impetus for our current focus on the micro-economies of detention.

By focusing attention on detention's internal microeconomies, this paper augments burgeoning scholarship in detention studies and carceral geographies (see for example Tyler et al., 2014; Moran et al., 2013; Mountz et al., 2013). We distinguish between macro- and micro-economies of detention, even though, in practice, they are linked. The macroeconomy of detention refers to the most immediately apparent exchange that takes place between the government and corporations with privatization, that of ownership or management. This exchange is typically measured as the amount the federal government pays "per bed" or "per detainee". It is regulated by law with a 34000 -detainee-per-day mandate and can be investigated by pursuing contracts, federal budget allocations, and corporations' earnings and shareholder reports. In contrast, micro-economies encompass exchanges that are linked to the infrastructure, everyday operation, and lived experience of detention. They embody what Cindi Katz describes as the "messy, fleshy stuff of everyday life" (2001:711) and, as such, exist at the scale of the detention facility. Simultaneously, consonant with the politics of scale (Marston, 2000), their reach extends into and beyond the everyday lives of detainees or a facility with links to families, communities, and actors in political, economic, and social spheres beyond a detention center. We can measure micro-economies by examining subcontracts for services such as food and healthcare, when available, within detention facilities. Yet, because they encompass lives and livelihoods, these micro-economies are more than a numeric measure. Given this, we want to not only highlight how detention micro-economies expand profits for private corporations but also call attention to how they impact the experience of detention. We are, thus, primarily concerned with investigating the contention that "what the privatization of detention does exceptionally well is to promote the commercialization of detention and the production of a commodity - the detainee" (Doty and Wheatley, 2013:434).

While there has been a good deal written about the expansion and privatization of this system at the macro-level, there remains a dearth of scholarly attention to the micro-level economies of privatized detention. Without doubt, this is due, in part, to the challenges of accessing these "closed contexts" as research sites (see Koch, 2013; Belcher and Martin, 2013). Furthermore, because private contractors are not accountable to the public in the same way that government is, accessing information can be extremely difficult, as we detail in the following section. Nonetheless, in this paper we begin to fill this void by sketching the complex array of services internal to immigration detention facilities, which have been subcontracted out and privatized. In this process, we demonstrate how money is made by additional private sector actors be- 
yond those who dominate detention contracts at the federal and state levels. Before turning to four micro-economies of detention that exemplify our aims, we outline the methodology used in our research.

\section{On methodology}

Our charting of four micro-economies comes out of an ongoing research project on immigrant detention in the New York City (NYC) metropolitan area. Our study concentrates on nine detention facilities that house immigrants taken into custody in the greater NYC area (NYC, the part of New York state to the east of NYC that is known as Long Island, ${ }^{1}$ and eastern New Jersey), most of them in eastern New Jersey. ${ }^{2}$ Reflecting the pattern nationwide, the majority of these facilities are run by private corporations, or nominally run by county governments who then contract with private companies. Of these nine facilities, large corporations like GEO Group and Community Education Centers (CEC) are dominant. The process of awarding the lucrative contracts for the management of some facilities in this study has come under scrutiny amidst charges of lack of transparency, cronyism, and campaign contributions by CEC owners and New Jersey elected officials (Lee, 2011; Wilwohl, 2011). Such charges emphasize the profits at stake consequent to the privatization of immigration detention. We focus on detention microeconomies in an effort to better tease apart the various strategies for maximizing these profits.

Our goals are threefold. One goal is to begin to identify the range of entities attempting to profit from detention by looking at contracts and subcontracts to do with the operation of detention facilities. The second goal is to identify and trace additional ways in which money is made on detention, beyond the money exchanged through formal contractual agreements. To these ends, we are pursuing a number of methodological strategies concurrently, some of which thus far are more successful than others. We include a description of the less successful strategies alongside the more successful ones in order to illustrate the challenges that can be encountered when researching an industry that, typically, is opaque and guarded (Belcher and Martin, 2013). The third goal is to contribute to knowledge regarding the consequences of detention privatization on migrant detainee experiences.

First, we are working to obtain facility-specific documents regarding contracts and subcontracts, standards, oversight and operations. While parties involved in detention operations do not routinely make contracts and other documents available, there are laws at the federal and state levels that require government agencies to fully or partially dis-

\footnotetext{
${ }^{1}$ Currently, immigrants taken into ICE custody in NYC and Long Island are transported within 24 hours to eastern New Jersey or upstate New York for detention.

${ }^{2} \mathrm{~A}$ complete list of facilities included in this study is available from the authors.
}

close requested information and documents. In August 2013, we filed two Freedom of Information Act (FOIA) requests with ICE, and three equivalent requests, called Open Public Records Acts (OPRA) requests, with counties in the state of New Jersey. These requests asked for a wide range of contracts pertaining to the operation of facilities, budgets, commissary lists, facility program and detainee work schedules, lists of items issued to detainees, and detainee handbooks. Unfortunately, and despite federal law requiring FOIAs to be filled within 20 days of filing, our FOIAs were not filled until October 2014 (right before this issue went to press; therefore this article does not include review of the FOIAs). To date only one of the three OPRAs has been filled; from this we received almost 2000 pages of documents to review regarding the Delaney Hall Detention Facility and the Essex County Correctional Facility - both in Newark, NJ. The OPRA request documents we received are a rich source of information, and we have triangulated these with other data (our interviews, published reports by other organizations, and journalistic accounts).

Second, we are gathering personal accounts regarding the inner workings of detention facilities. We conducted semistructured interviews with 15 people who have been inside detention facilities themselves in different capacities, or who have worked with detainees (during detention or after detention): lawyers, members of legal assistance and human rights organizations, members of detention visitation groups, and one former detainee. ${ }^{3} \mathrm{We}$ asked participants questions regarding facility schedules, policies, and routines; different entities they witnessed working in or in service of facilities; detainee experiences, including personal needs, communication, work, complaints, and expenses; and observed differences between facilities. In addition, one of the authors participated in a volunteer detention visitation program at one of the facilities in the study, through which she observed the spaces of the facility to which visitors were allowed and engaged in informal conversations with detainees. To protect the anonymity of participants (and organizations to which they belong), we refer to quoted interviewees by their relationship to detention: lawyer, activist, or detainee. Finally, we triangulate data gathered in the present study with the growing number of published reports and media regarding the conditions and consequences of detention privatization (see, for example, Barry, 2009a, b; N.Y.U. Immigrant Rights Clinic, 2010; Bernstein, 2010; ACLU, 2011). It is important to note that while there is, of course, variety among the many detained individuals and detention facilities, patterns emerging across facilities suggest there is notable consistency in migrants' overall experiences of detention.

\footnotetext{
${ }^{3}$ Identifying and successfully contacting former detainees has proved the most challenging; the majority of detainees are eventually deported, and those who are released into the United States are typically difficult to locate and also hesitant to discuss their experience for various reasons.
} 


\section{Specific micro-economies}

The act of detaining people, often for extended periods of time, instantly creates a population with needs pertaining to daily living to be filled, as well as generating a range of additional services that must be provided in the management and control of this population. In this section, we first examine commissary systems, through which detainees make purchases, most of which, we argue, are necessitated by the conditions of detention. The second micro-economy is communication, where profits are made from detainees' need to communicate with the outside world in order to advocate for themselves or simply to maintain family ties. Third, we discuss how labor is extracted from detainees for the daily maintenance of detention facilities. Though paid at rates that barely register in the world outside detention, detainees often clamor for these jobs in order to make necessary purchases. Fourth, we consider the costs (and profits) related to detainee transportation to and from detention facilities for services that cannot be provided within.

\subsection{Detention facility commissaries}

Through examination of the micro-economy of facility commissaries, we see how detention providers make money by not providing detainees with objects and services that they need or desire, and withholding rights theoretically bestowed by existing law. As signaled repeatedly by a number of reports generated by human-rights-focused organizations and journalists (see, for example, Amnesty International, 2009; Human Rights Watch, 2009; ACLU, 2012), many facilities provide the bare minimum of services required and often struggle (and sometimes fail) to meet rudimentary standards. ${ }^{4}$ Profits are undoubtedly increased in this lack; that is, facilities do not pay for what they do not provide, thereby leaving more of the per "bed" fee paid by ICE for profit. Importantly, there is another consequence of the poverty of provision: the creation of consumer demand on the part of detainees. This is a demand that can then be satisfied by selling items to detainees, at a price set by the seller.

Our research indicates that detention facilities routinely have some type of store, called a commissary or kiosk, that sells items to detainees. Detainees typically make purchases by filling out a request, as described in this excerpt from the Delaney Hall Detention Center Detainee Handbook obtained in the OPRA (page 41):

\footnotetext{
${ }^{4}$ Importantly, and despite the 2011 federal Performance-Based Detention Standards discussed above, it is a system with only "guidelines" in place for how facilities should be run and detainees treated, little oversight, and rare enforcement.
}

\section{VENDING MACHINES AND COMMISSARY}

This facility has no vending machines for detainee use.

Commissary procedures are as follows:

- Detainees will be provided with a commissary order form according to a schedule posted in the housing area. Detainees shall complete the order form and submit it to the commissary officer at the posted pick up time.

- The items will be brought to you at your housing unit on the posted day.

- Commissary Lists of stocked items will be provided to the detainees on a regular basis.

One participant who had been detained for 5 weeks at Delaney Hall explains the specifics of how commissaries operate: "You get a list of available items, choose what you want and put your code and name. They take the money out of your account, and bring things to you on Wednesdays and Fridays." Advocates we interviewed, former detainees interviewed after deportation (Hiemstra, 2012, 2013, 2014), and numerous human rights organizations reports detail similar purchase systems throughout the US detention system.

As a member of a human rights organization told us, the commissaries can be seen by detainees as a "lifeline". The conditions of detention - how detainees are made to move through highly prescribed daily routines - create high demand for what the commissary sells. Perhaps the largest demand on commissaries results from a common lack of sufficient food. Also, as a former detainee complained, the quality of the food can be poor: "The food is garbage, so you have to buy extra." The demand for supplemental food also pertains to quantity. The advocate who described commissaries as a lifeline explained, "Food is horrible in facilities, [detainees are] given portions so small that they are frequently hungry." The way in which meals are scheduled may add to detainees' desire to purchase food from commissaries. At Delaney Hall, for example, meals are at 6:45 a.m., 12:00 p.m., and 5:00 p.m., with no food offered in between. A lawyer who frequently enters facilities to meet with clients suggested that such scheduling may be strategic in order to encourage food purchases. Detention facilities have an unregulated ability to set prices, and data suggest that both advocates and detainees perceive the prices as unfairly inflated. For example, a volunteer detention visitor reported, "Detainees will call us on a regular basis and tell us how expensive the food is. Because they get such small portions and it's tasteless (it's prison food), they'll buy food if they have money... [ramen] noodles they pay $\$ 3.00$ for a small bag. 
They can buy rice, that costs about $\$ 5.00$ a bag." ${ }^{5}$ To provide some comparison, bags of ramen noodles sold in a typical US food store would cost between fifteen cents and one dollar.

Sales to these captive consumers are not limited to food. Our participants described extensive commissary lists, including toiletries, clothing, electronics, and recreational items like games and cards. Again, the conditions of detention push detainees to make certain purchases. For instance, while facilities are required to provide essential toiletries like shampoo, soap, and razors, what is provided is often insufficient. Detainees quickly run out of the meager supplies, or, as a former detainee explained, "they are poor quality so most [detainees] want to buy." Another common complaint from detainees is that facilities are kept at low temperatures (ACLU, 2011). Consequently, many want to purchase long underwear to keep warm (Hiemstra, 2014). Additionally, many detainees are incarcerated for weeks and even months. The monotony of life in detention fosters a desire to purchase items for recreation. A man previously detained in Delaney Hall explained, "Anything you want to do other than TV you have to buy - cards, paper and pen for letter writing, dominoes." We provide these examples not because of a high dollar amount, but because they demonstrate ways in which the intimate details of detainees' routines are crafted - whether intentionally or unintentionally - in ways that turn them into willing, even desperate, consumers with only one outlet for their consumption.

\subsection{Curtailing communication with the outside world: phone contracts}

The 2011 PBNDS state that "detainees shall have reasonable and equitable access to reasonably priced telephone services" (p. 359) and, further,

contracts for such services shall comply with all applicable state and federal regulations and be based on rates and surcharges comparable to those charged to the general public. Any variations shall reflect actual costs associated with the provision of services in a detention setting (p. 360).

Our second micro-economy - communication and, more specifically, phone contracts - illustrates that, for detained migrants, reality is a striking contrast to these standards. ${ }^{6}$ Although phone services are provided invariably they are available at exorbitant costs that frequently prohibit detainees from maintaining links with loved ones, community advocates, and legal representatives.

\footnotetext{
${ }^{5}$ The provision of food/cafeteria service is another important detention micro-economy; discussing it here is beyond the scope of this article.

${ }^{6}$ Email is another facet of this micro-economy that provides a lucrative revenue stream for private companies; discussing it here is beyond the scope of this article.
}

Like the prison system, in immigration detention, center operators contract out telephone services to private communications firms. A handful of companies, including Global Tel*Link, Securus, Century Link and Pay-Tel, dominate this market. The services these companies provide are not proprietary, yet contracts awarded involve significant markups on the cost of phone calls that migrants and their families must bear. Interestingly, among the reasons for the high costs of communication is not corporate greed per se; instead, they result from commissions paid to local and state governments. Subcontractors are invited to submit bids to county and state governments to provide telephone and communication services to detention facilities. It is common practice for bidders to offer a menu of options, each with different price points for local, intra-state, and inter-state phone calls. The differing price points reflect different commission rates. For example, our OPRA records indicate that commission rates for intrastate and inter-state phone calls vary between 15 and $57 \%$ in one service provider's bid. ${ }^{7}$ One activist notes, however, that the lowest rates are "just window dressing" meaning bids that have been awarded invariably use the higher commission rates.

Local governments earn millions of dollars in connection with these commissions. For instance, in 2012, New Jersey's Essex County government, through their contract with Global Tel*Link, received a commission rate of $54 \%$ on phone services to the county jail where immigrant detainees are held; this translates into an annual income of USD 925000 received by the county government in association with telephone commissions (New Jersey Advocates for Immigrant Detainees, 2013). Profits are also generated at the state level. As an immigrant rights activist whom we interviewed noted, the costs of calls made from $\mathrm{NJ}$ state prisons include a $41 \%$ commission; consequently, the state government makes between USD 3 and 6 million annually.

In practical terms this means that immigrant detainees pay phone rates approximately 20 times higher than prevailing rates offered by telephone service providers operating outside detention (NJ Advocates for Immigrant Detainees, 2013). Even more concretely, one volunteer visitor noted that a "15-minute phone call from New Jersey to New York costs almost $\$ 15.00$." For comparison, the cost typically paid by either a land line or cell phone user would certainly be less than USD 2, and potentially even a fraction of that. As a result detainees often feel compelled to earn money by participating in so-called "voluntary" work programs within detention facilities where "one month's wages would cover the cost of a 15 min phone call to New York" (NJ Advocates for Immigrant Detainees, 2013:4).

\footnotetext{
${ }^{7}$ Local calls are typically charged at a flat per minute rate. Because detainees are often transferred from their place of residence to out-of-state detention facilities, they must make intra-state and inter-state calls to communicate with loved ones.
} 
Governments are not the only institutions profiting from this micro-economy; private companies certainly garner substantial profits too. Communication with those outside detention centers is available via collect calls or a calling card system only. Detainees can purchase phone cards, usually on a weekly basis, or a family member or contacts outside the facility can add money to a detainee's phone account. Private companies add fees for every transaction in this process. For example, detainees are routinely charged USD 5.00 to add money to their account; they must put money on in certain increments; detainees are not informed prior to a call what rate they will be charged; if money on the account is not used within a certain length of time it is forfeited; when detainees are transferred to another facility they are charged to transfer that money and then charged to open up an account at another facility. Thus, at every turn detainees are subject to "predatory phone rates" (CIVIC, 2013:2). ${ }^{8}$

For detainees the effects of this privatized, subcontracted micro-economy are manifold. Not only do migrants suffer greater isolation from the community than is already inherent within the reality of detention; in addition, the high cost of communication places undue financial burdens on detainees, their family members, and advocates who endeavor to provide emotional and practical support to detainees. Additionally, costly phone calls mean that access to legal representation, already limited by being deemed a "privilege" rather than a right (Amnesty International, 2009:30), is further curtailed for many detainees. Because legal representation is crucial to positive outcomes in immigration hearings (NYIRS, 2011) the inability to access legal support, which is exacerbated by the high cost of communication, means that more detainees end up being deported.

\subsection{Detainee labor}

There are a number of ways through which these captive consumers obtain the money that they spend in detention. Some detainees have family and friends who can send money for their commissary account. Some have money on their person when detained, which may then be deposited into their account. Without these funds, or when they run out, detainees

\footnotetext{
${ }^{8}$ It should be noted that in 2013 the Federal Communications Commission issued a ruling in a 10-year-old case pertaining to the high cost of phone calls in federal and state prisons (Wright vs. CCA, 2000) with the result that a cap was placed on the cost of certain calls. One telephone company (Securus) subsequently successfully sued for a stay on implementing facets of the FCC's ruling; hence no further revisions will be made to cost structures until further legal hearings ensue. Nonetheless, this case prompted a similar campaign by immigration advocates for detained immigrants, and some facilities in NJ have renegotiated contracts for instate and inter-states phone rates in state facilities where migrants are detained. While this is a welcome development, actual compliance is uncertain; thus the impact for detainees remains unclear (see CIVIC, 2014).
}

may be desperate for any opportunities to earn more money to spend in detention. This is where "voluntary" work programs in detention facilities come in. Most facilities offer some type of "employment" to detainees. The Delaney Hall Detainee Handbook (p. 44), for example, states, "Every effort will be made to provide you an opportunity to participate in the voluntary work program." The Essex County Correctional Facility Detainee Handbook (p. 39) includes, "All individuals who are detained at the Essex County Correctional Facility are eligible on a voluntary basis for available ICE Detainee worker openings." What's more, Essex's Handbook (p. 39) goes on to characterize working as a privilege: "Work is a privilege that may be rescinded for not reporting for work, appearing in an unsanitary condition, or performing unsatisfactorily."

There are several important points to be made regarding these work “opportunities". First, detainees are typically paid one to three dollars per-day, rates that have been upheld in court (Moreno, 2012). Second, the work is often difficult, taxing, and tedious - tasks such as cleaning, laundry, maintenance, or kitchen work. As a former Delaney Hall detainee explained,

\section{Those that work have to work very hard. For clean- ing, start at 7 a.m. For kitchen, start at 6 a.m. - they help cook, then clean in kitchen and in eating area, finish breakfast at about 10 a.m., then at 11:30 have to come back for lunch, repeat, then have to work again for dinner.}

Third, there is often not enough work to satisfy detainee demand. Given the rate of pay and the difficulty of the work, at first glance this fact may be surprising. If we return to the purchases made by detainees described in the first two microeconomies, however, this desire to work makes sense. As this same former detainee explained,

Many more people want jobs than there are jobs to have. There are only six to ten of each type of assignment. But people want the jobs when they don't have any money. They will work a couple of weeks just to be able to make a phone call.

Essentially, the way in which detention life is structured means that detainees are eager for jobs that may earn them as little as 12 cents (USD 0.125) per hour.

We want to emphasize here that while participation in these so-called "voluntary" work programs is not overtly coerced - and indeed, presented as a privilege - the conditions of detention mean that coercion can be disguised, concealed by created consumer demand, by personal attempts to make detention bearable. What's more, detention contractors profit in two ways on detainee labor. Labor for some of the basic services for which they are responsible, such as food, cleaning, laundry, is achieved at significantly reduced cost to them. One human rights organization employee we interviewed estimated that one 187-bed facility saved about USD 5 to 6 mil- 
lion per year. Then, the wages that they do pay detainees come back to the detention providers when detainees purchase things that the facilities sell (Fernandes, 2007; Moreno, 2012). Detention providers have created a remarkable system for profit maximization by creating conditions that drive detainees to make purchases at inflated prices, work for nearly nothing, and then essentially return the bulk of their earnings to the detention facility.

\subsection{Captive on the outside}

While the modus operandi of detention is to maintain detainees inside of detention facilities, there are a number of reasons that occasion mobility outside of the containing walls. We identify several external movements as part of a fourth micro-economy of detention because they entail significant expense and effort for detention operators.

First, detainees are frequently transferred between detention facilities (Gill, 2009; Human Rights Watch, 2009; Hiemstra, 2013). Reasons for these transfers can include lack of "bed space" at a particular facility, and moving a detainee closer to a facility from which he or she will be deported. Advocates claim that detainees are also transferred strategically, such as to remove detained migrants from support networks and legal assistance (Morawetz, 2005; Kanstroom, 2007; Human Rights Watch, 2009); or in retribution for behavior found disagreeable by facility managers, such as not complying with requests, asking for additional privileges, or attempted organizing (Dow, 2004; Gill, 2009; Bernstein, 2010). Data from our project support these previous findings. For example, the director of a visitation program reported that, "We are also getting calls from detainees who are being threatened with being moved if they don't comply with CEC staff." Detainees' final transportation within the detention system, of course, is for deportation.

Second, detainees must occasionally leave and return to the same facility. These excursions may be for court appearances, visits to the ICE field office, visits to the migrants' consulate, and medical attention that cannot be provided within the detention facility. It is important to note that efforts to minimize opportunities for venturing outside the facility have significant consequences for detainees. For example, many detainees' "appearances" in court take place by video. Advocates note that migrants' lack of physical presence in front of a judge negatively impacts their case outcome (Human Rights Watch, 2009). Additionally, management reticence in allowing detainees to exit for medical care can have dire consequences for their mental and physical well-being, and is part of an ingrained culture in which detainee medical needs are neglected (Bernstein, 2010; ACLU, 2011).

Still, detainees are sometimes transported to and from facilities. Our scrutiny of detention center contracts received through OPRA requests shows that these excursions constitute a significant expense. Costs include vehicles, vehicle maintenance, fuel, and drivers. Different detention facilities have different transportation arrangements and providers. Transportation may be executed by ICE, the US Marshals Service (particularly in the case of deportation), the entity with whom ICE directly contracts (be it a county or private company), or subcontracted by that entity to yet another company. Individual facilities may purchase vehicles for the transport of cargo as well as people. Symbolic of the securitization of migration and framing of migrants as security threats, in detention contracts, budgets, and billings we have reviewed thus far, "transportation" (to wherever it may be) includes the provision of armed guards to accompany any transported and hospitalized prisoners, another important component of this micro-economy. Our analysis of documents obtained shows that there is a welter of actors who receive monetary compensation related to the extra-facility transportation of detainees.

\section{Conclusion}

Securitization of immigration, the rise of interior immigration policing, and forces of carceral privatization have occasioned a remarkable expansion of immigrant detention throughout the United States. This paper has illustrated that tracing political and economic geographies inside detention facilities, in addition to exposing the direct links between government money and detention facilities, is critical for understanding this expansion and its consequences. We have explored four micro-economies evident in detention facilities in the greater NYC area. These economies show that detained migrants' social reproduction - their needs and daily routines - are tailored in ways that produce migrants as both captive consumers and laborers. Theirs is a captivity borne of a continued securitization of immigration, where migrants are relentlessly criminalized and dehumanized in ways that turn them into targets for the extraction of profit. Recognition of multiple micro-economies also highlights the fact that the numbers of individuals and entities invested in the incarceration of immigrants proliferate in tandem with the objectification of detainees.

While this paper offers an important starting point, there still remains a substantial dearth of research on the relationship between the interior operations of facilities and the centrality of detention in contemporary immigration enforcement regimes. There are many additional micro-economies which have not yet been examined. One, for example, is the provision of all the various products required to maintain a large incarcerated population, from cleaning supplies to foodstuffs to toiletries for detainees. There are myriad entities that compete to attain such contracts (Fernandes, 2007). Another is the vast number of individuals employed by detention facilities - such as food service, maintenance staff, and administrative personnel. There are other, more hidden economies that develop as well. For instance, detainees may also be captive targets for theft. Whether by design or, per- 
haps, due to the chaos of the detention and deportation apparatus, detainees often lose money and possessions in the system (Hiemstra, 2013). Also, as a result of their forced consumerism, bartering economies develop among detainees, in which skills, material items, and money are exchanged.

Another important area for future research is the variation in micro-economies between places. While this study has focused on facilities in the greater NYC area, previous studies suggest that there exist significant differences in detention according to geographic location (Hiemstra, 2013; TRAC, 2013). One recent report (TRAC, 2013) found significant contrasts in detention durations on a state-by-state basis, which is partly related to the changing geographies of immigration enforcement discussed earlier. Future inquiries should explore how detention micro-economies differ between places that routinely hold migrants for longer versus shorter periods of time, and what these differences reveal. For instance, do commissary and phone systems exhibit greater development in facilities where migrants are detained for longer periods of time? Variations between geographically proximate facilities also need attention. Despite the existence of guidelines intended to standardize facility operations and procedures and ensure a minimum of care for detainees the 2011 Performance-Based National Detention Standards (PBNDS) - there is a lack of nationwide oversight or uniform enforcement. This leads to tremendous variation in the degree of compliance and, therefore, in the experiences of detainees. Our research to date indicates that variations exist not just from state to state, or county to county, but also from facility to facility.

Our focus on the multiplying micro-economies operating in detention reveals the thin membrane that separates carceral boundaries and effectively links public government and institutions with private sector actors. This porosity is troubling on many levels. In this paper we have highlighted some of the effects for detained migrants. Detention microeconomies are also entwined with the lives of loved ones and thus spill out into communities beyond the boundaries of detention centers. The ties between private and public sector actors also make investigations such as ours more cumbersome, yet also more necessary. Research becomes cumbersome because private corporations are not accountable to the public in ways that government is. As a consequence, accessing information necessitates greater persistence and more inventive approaches to research. This research is also more necessary precisely because governments are ultimately subject to public approval and accountable to their constituents, and the increasingly entwined character of migrant detention - from the macro- to the micro-level - means voters and taxpayers have a stake in what goes on in migrant detention centers. Given this, voters can potentially call into question the manner in which private corporations are profiting from the detention of migrants at the expense of taxpayers and under the aegis of voter assent. By identifying and scrutinizing detention micro-economies, this paper provides fodder for such questioning and, we hope, contributes to the project of undermining the expanding detention regime.

Acknowledgements. We are very grateful to Jen Turner for patient guidance on our contribution to this special issue. We thank the two anonymous reviewers and the editor of Social Geography for their constructive comments and feedback.

Edited by: J. Turner

Reviewed by: three anonymous referees

\section{References}

ACLU: Outsourcing responsibility: The human cost of privatized immigration detention in Otero County, http://aclu-nm.org/ wp-content/uploads/2011/01/OCPC-Report.pdf (last access: 20 September 2014), 2011.

ACLU: Prisoners of profit: Immigrants and detention in Georgia, http://www.acluga.org/files/2713/3788/2900/Prisoners_of_ Profit.pdf (last access: 20 September 2014), 2012.

Amnesty International: Jailed without justice: Immigrant detention in the USA, Amnesty International USA: Washington DC, 2009.

Barry, T.: The new political economy of immigration, Alternet February 17, http://www.alternet.org/story/127471/the_new_ political_economy_of_immigration (last access: 20 September 2014), 2009a.

Barry, T.: The National Imperative to imprison Immigrants for profit, Americas Program Report, 10 March, http://www. cipamericas.org/archives/1662 (last access: 20 September 2014), 2009b.

Belcher, O. and Martin, L. L.: Ethnographies of closed doors: Conceptualising openness and closure in US immigration and military institutions, AREA, 45, 403-410, 2013.

Bernstein, N.: Officials hid truth of immigrant deaths in jail, The New York Times, 9 April, http://www.nytimes.com/2010/01/ 10/us/10detain.html?_r=1\&ref=incustodydeaths (last access: 20 September 2014), 2010.

Bigo, D.: Security and immigration: Toward a critique of the governmentality of unease, Alternatives, 27, 63-92, 2002.

Cervantes-Gautschi, P.: Wall Street and the criminalization of immigrants, Americas Program, 10 June, http://www.cipamericas. org/archives/3304, 2010.

Coleman, M.: Immigration geopolitics beyond the Mexico-US border, Antipode, 39, 54-76, 2007.

Coleman, M.: What counts as geopolitics and where? Devolution and immigrant insecurity after 9/11, Ann. Assoc. Am. Geogr., 5, 904-913, 2009.

Community Initiatives for Visiting Immigrant in Confinement (CIVIC): Comments to Federal Communications Commission, FCC Proceeding 12-375, "Wright Petition”, March 2013, 2013.

Detention Watch Network: A brief history of private prisons in immigration detention, http://www.detentionwatchnetwork.org/ privateprisons_note2 (last access: 19 December 2014), nd.

Detention Watch Network: Alternatives to detention, http:// www.detentionwatchnetwork.org/atd, last access: 19 September 2014a. 
Detention Watch Network: About the U.S. Detention and Deportation System, http://www.detentionwatchnetwork.org/resources, last access: 19 September 2014b.

Doty, R. L. and Wheatley, E. S.: Private detention and the immigration industrial complex, Int. Pol. Soc., 7, 426-443, 2013.

Dow, M.: American Gulag: Inside U.S. immigration Prisons, University of California Press, Berkeley and Los Angeles, 2004.

Fernandes, D.: Targeted: Homeland Security and the Business of Immigration, Seven Stories Press, New York, 2007.

Feltz, R.: Homeland Security - A new migration policy: producing felons for profit, NACLA Report on the Americas, November/December, 26-30, 2008.

Feltz, R. and Baksh, S.: Business of Detention, in: Beyond Walls and Cages: Prisons, Borders and Global Crisis, edited by: Loyd, J., Mitchelson, M., and Burridge, A., U. Georgia Press, Athens, GA, 143-151, 2012.

Gill, N.: Governmental mobility: The power effects of the movement of detained asylum seekers around Britain's detention estate, Polit. Geogr., 28, 186-196, 2009.

Golash-Boza, T.: The immigration industrial complex: Why we enforce immigration policies destined to fail, Sociol. Compass, 3, 295-309, 2009.

Harvey, D.: A brief history of neoliberalism, Oxford University Press, Oxford, 2005.

Hiemstra, N.: Geopolitical reverberations of US migrant detention and deportation: The view from Ecuador, Geopolitics, 17, 293$311,2012$.

Hiemstra, N.: "You don't even know where you are": Chaotic geographies of US migrant detention and deportation, in: Carceral Spaces: Mobility and Agency in Imprisonment and Migrant Detention, edited by: Moran, D., Gill, N., and Conlon, D., Ashgate, Surrey, 57-76, 2013.

Hiemstra, N.: Performing homeland security within the US immigrant detention system, Environ. Plann. D, 32, 571-588, 2014.

Human Rights Watch: Locked Up Far Away: The Transfer of Immigrants to Remote Detention Centers in the United States, Human Rights Watch, New York, 2009.

Immigration and Customs Enforcement (ICE): PerformanceBased National Detention Standards, http://www.ice.gov/ detention-standards/2011/ (last access: 14 March 2014), 2011.

Justice Policy Institute: Gaming the system: How the political strategies of private prison companies promote ineffective incarceration policies, Justice Policy Institute: Washington DC, www.justicepolicy.org (last access: 14 March 2014), 2011.

Kanstroom, D.: Reaping the harvest: The long, complicated, crucial rhetorical struggle over deportation, Connecticut Law Rev., 39, 1911-1922, 2007.

Katz, C.: Vagabond capitalism and the necessity of social reproduction, Antipode, 33, 709-728, 2001.

Kerwin, D. and Lin, S. Y.: Immigrant detention: Can ICE meet its legal imperatives and case management responsibilities, Migration Policy Institute, Washington DC, 2009.

Koch, N.: Introduction: Field methods in "closed contexts": undertaking research in authoritarian states and places, Area, 45, 390395, 2013.

Lee, E.: Cronyism, political donations surround detention center in Newark, says report by immigrant advocates, NJ.com, 21 December, http://www.nj.com/news/index.ssf/2011/12/essex_ county_comes_under_fire.html (last access: 20 September 2014), 2011.

Martin, L.: "Catch and remove": detention, deterrence, and discipline in US noncitizen family detention practice, Geopol., 17, 312-334, 2012.

Marston, S.: The social construction of scale, Prog. Hum. Geog., 24, 219-242, 2000.

Miroff, N.: Controversial quota drives immigration detention boom, The Washington Post, 13 October, http://www.washingtonpost.com/world/controversial-quotadrives-immigration-detention-boom/2013/10/13/09bb689e214c-11e3-ad1a-1a919f2ed890_story.html (last access: 20 September 2014), 2013.

Moran, D., Gill, N., and Conlon, D.: Carceral Spaces: Mobility and Agency in Imprisonment and Migrant Detention, Ashgate, Surrey, 2013.

Morawetz, N.: Detention decisions and access to habeas corpus for immigrants facing deportation, Boston Coll. Third World Law J., 25, 13-33, 2005.

Moreno, L.: For-profit immigration detention center underpays detainee workers, overcharges for services, post 27 July, 2012, http://www.mycuentame.org/you_won_t_beleive_how_ underpaid_workers_in_this_for_profit_immigration_detention_ center_are_paid (last access: 19 September 2014), 2012.

Mountz, A., Coddington, K., Catania, R. T., and Loyd, J.: Conceptualizing detention: Mobility, containment, bordering, and exclusion, Prog. Hum. Geog., 37, 522-541, 2013.

New Jersey Advocates for Immigrant Detainees: Comments to Federal Communications Commission (FCC), March 2013, www. njphonejustice.org (last access: 14 March 2014), 2013.

N.Y.U. Immigrant Rights Clinic: Locked Up But Not Forgotten, http://afsc.org/sites/afsc.civicactions.net/files/documents/ LockedUpFINAL.pdf (last access: 14 March 2014), 2010.

Office of Immigration Statistics: Immigration Enforcement Actions: 2011, Department of Homeland Security, Washington DC, 2012.

Schriro, D.: Immigration Detention Overview and Recommendations, 6 October 2009.

Simanski, J. F. and Sapp, L. M.: Immigration Enforcement Actions 2012, Office of Immigration Statistics, Department of Homeland Security, Washington DC, 2013.

Tyler, I., Gill, N., Conlon, D., and Oeppen, C.: The business of child detention: Charitable co-option, migrant advocacy and activist outrage, Race Class, 56, 3-21, 2014.

TRAC: Legal noncitizens receive longest ICE detention, TRAC Reports, http://trac.syr.edu/immigration/reports/321/ (last access: 19 September 2014), 2013.

Varsanyi, M.: Rescaling the "alien", rescaling personhood: Neoliberalism, immigration and the state, Ann. Assoc. Am. Geogr., 98, 877-896, 2008.

Wilwohl, J.: Feds may reconsider county jail deal, Newark NJ Patch, 17 August, http://newarknj.patch.com/groups/ politics-and-elections/p/feds-reconsider-essex-county-jail-deal (last access: 20 September 2014), 2011. 